the relationship between variativity and language norm. Then we discussed the place of variant forms among language variables and the connection between variants and the invariant. Finally, we reviewed the types of variants at diverse levels of language based on the Hungarian and international literature.

We are interested in this area because it is known by Hungarian and foreign linguists even if in the published literature it is analyzed from the aspect of sociolinguistics and not from a prescriptive viewpoint. Therefore, linguists tend to use different terminology in dealing with variativity, and that is the reason why there is overlapping and ambiguity between variativity and similar lexico-semantic relationships (synonymy, polysemy, paronymy) as well as other linguistic phenomena (word split, doublets, convergent development of form and meaning).

Keywords: symmetry/asymmetry, language variability, language variativity, language change, language norm, invariant.

\title{
Miskóltzy Ferentz orvosi szavai
}

\section{Bevezetés}

Miskóltzy Ferentz sebész, orvos, tanácsos életéről (akit a nyelvújítás elöhírnökének tekinthetünk) keveset tudunk. Többnyire azt olvashatjuk, hogy 1697. febr. 21.-1771. okt. 30-ig élt. Az biztos, hogy 1730 körül vette feleségül Murai Katalint, és ekkor telepedett le Győrben. 1733-tól több gyermeke is született. Mint sebész kezdte meg a tevékenységét (egyes források szerint céhmester volt). 1734-ben megválasztották városi kapitánynak. 1748-tól Győr város orvosa lett. Petz Aladár (1929: 24) Mayer Ferencre hivatkozva megírja, hogy 1748-ban az oklevelek tanúsága szerint Miskóltzy részt vett a Szentháromság kórház alapkőletételénél, és hogy később a kórházban dolgozott. Az utóbbit az bizonyítja, hogy 1761-ben Miskóltzy Ferentz sebész-céhmester, chirurgus nevével egy nőbeteg lábtörésével kapcsolatosan lehet találkozni a számadásokban, és innen megtudjuk azt is, hogy évi salaruma 8 forint volt, valamint azt is, hogy 1762-től utódja Bander Simon lett (i. m. 58). Azt, hogy orvosként emlegetik, talán azzal lehet magyarázni, hogy nagyon kevés orvosdoktor volt Magyarországon, ezért néhány megye kénytelen volt chyrurgusokat alkalmazni physicusként. Bács vármegye például 1762-ben nem talált olyan orvost, aki évi 600 Ft-ért elvállalta volna a megyei physicus szerepét. Aki számításba jöhetett volna, azt a győri püspök fogadta szolgálatába. A súlyos járványok miatt azonban kénytelenek voltak felvenni föorvosnak egy sebészt (Simon Katalin 2011: 59). Az 1760-as évektől már általánossá vált, hogy bizonyos sebészeket foglalkoztattak városonként, megyénként évi juttatás fejében orvosnak (i. h.). Miskóltzyt 17601771-ig városi tanácsosnak is megválasztották (Kapronczay 2004: 1085; Csillag István 1962: 1083) 


\section{Miskóltzy könyvírói munkássága}

A 16. században azokat, akik könyvet írtak, sokra becsülték, így Miskóltzyt is, akitől az első sebészeti kézikönyv származik: a Manuale chirurgicum, avagy chirurgiai uti-társ (1742), amely Norr német sebész (Norr Erhardt: Chirurgiser Wegweiser, 1706) munkájának magyar nyelvü fordítása, pontosabban átdolgozása, ugyanis Miskóltzy több fejezete nincs meg Norrnál. Maga ezt írja az ajánlásban (az ajánlás címe: „Kedves olvasóm, édes hazám-fia!”):

„Meg-vallom ezen Könyvnek ki-botsátásában, fundamentomúl vettem egy NémetOrszági hires Chirurgusnak sok Doctorok által approbált munkátskáját, de hogy az tsúpán egyedül abbúl származott vólna azt nem mondhatom, holott más deák Könyvekböl kedves Olvasómnak hasznára, némely hasznos dolgokat szedegettem, és munkátskámhoz toldottam” (XI-XII).

A fordítást valójában nem ő készítette, hanem Torkos József, a tudós győri pap, az ottani evangélikus iskola rektora (Magyary-Kossa Gyula 1940: 413). Miskóltzy könyve a borbélysebészek mestervizsgájának anyagát tartalmazza kérdésekben és feleletekben (i. m. 125).

Miskóltzy az ajánlásban megfogalmazza a chirurgussal kapcsolatos követelményeket. Ezzel sok tekintetben meghaladta a korát:

„Keresztényi jó indulattal, Isteni félelemmel, és felebarátyához nagy szeretettel kelletik lenni, józanon és víg erköltsel, 's szép termettel birni, sok szép Orvos Könyveknek olvasásának gyakorlásával, [Semmelweist megelőzve; vö. Ralovich 2015: 357] kezeinek tisztán-való tartásával fel-ékesitve lenni; azonban mind jobb, mind pedig bal-felé szorgalmatossan tudjon forgolódni; vastag vagy nehéz dolgot ne tégyen, szép Musikára szoktassa magát, hogy az ő ujai szép gyengén maradjanak, ne talántán az erős dolgoktól kezei meg-szőrösedjenek, avagy rezketni kezdjenek" (2-3).

A könyv tudományos értékéről különböznek a vélemények. Az anatómiai részről maga is azt írja, hogy „nincsen [...] minden fogyatkozás nélkül”. Korbuly Györgynél (1939-1942) ezt olvashatjuk:

„Az így szerzett [borbélysebészi] képesség elég alacsony fokú volt, amint azt Miskóltzy Ferentz 1742-ben Győrött kiadott, tankönyvül is használt Manuale chirurgicum, avagy chirurgiai uti-társ címú müve is bizonyítja."

Fekete Károly viszont kiemeli, hogy

„Miskóltzy Ferentz Manuale Chirurgicum-a [...] ma is izgalmas, érdekes olvasmánya a baleseti sebészeknek" (2016: 161). Csillag István is elismerően ír Miskóltzyról: [a sebészeti rész] „kitúnő, sok vonatkozásban ma is helyes és messze túlhaladja korát" (1962: 1084).

Ács Géza a Magyar Traumatológiai Társaság megalakulásának 50. évfordulóján tartott beszédében szintén úgy nyilatkozott, hogy a tanulatlan borbély céhmesterek közül toronymagasan kiemelkedő, európai müveltségü tudós sebész volt Miskóltzy Ferentz (Ács Géza 2016). 


\section{A sebészet helyzete a 18 . században}

A 18. századi sebészet kettős arculattal rendelkezett. Egyfajta átmeneti korszak volt ez. Egyrészt a természettudományi ismeretek fejlődésének, az anatómiának a beépülése a tudásanyagba és ennek mind orvosok, mind sebészek közötti elterjedése; másrészt a korábbi századokból örökölt galénoszi-hippokratészi alapelvek megmaradása és fokozatos kiszorulása jellemezte.

Ennek megfelelően Miskóltzy könyvének egyik része valóban értékes tudnivalókat tartalmaz. Másik része, amely az előző századok hivatalos orvostudományát tükrözi: babona.

\section{A könyv nyelvezete}

A könyv nem sokkal a török uralom megszünése után született, amikor a magyar tudományos nyelv még valójában alacsony színvonalú volt. A szerző is küszködött a magyar nyelvvel, különösen akkor, amikor orvosi szakszavakat használt.

Miskóltzy könyve közel 400 orvosi megnevezést tartalmaz (a gyógynövények és a gyógykészítmények nevein kívül). Gyakran használt csupán latin (olykor német) kifejezéseket (több mint 100 alkalommal). A latin kifejezések közül néhánynak nagyon nehezen vagy nem is találtam meg a magyar megfelelöjét sem Brencsánnál, sem a régebbi latin-magyar szótárakban. - Ezek külön tanulmányt érdemelnének. Több esetben a latin (vagy ritkábban német) szakszónak közölte a magyar megfelelőjét is, de használt csupán magyar megnevezéseket is.

\subsection{A latin (olykor német) szavak a munkában, a szerző által megadott magyar kifejezéssel}

Itt csupán azokat az eseteket sorolom fel, amelyek Miskóltzy egyedi szóalkotásai vagy körülírásai, vagy amelyek nem tökéletes fordítások, vagy nála fordulnak elő először. A szövegben a latin és a magyar megfelelő sorrendje változó. A könnyebb tájékozódás érdekében itt mindenkor az idegen szó áll elöl. A szavakat eredeti helyesírással írtam le. Ha szükséges, megadtam a szó mai jelentését is. ${ }^{1}$

Anevrisma: érnek mérges dagadása (Miskóltzy 1742: 104) 'a verőér helyi tágulata'; Angina: Torok-gyík (i. m. 116) 'torokgyulladás'; Aphtha: szájban való kelevény (i. m. 226) 'fehér színű fekélyes folt a nyálkahártyán'; Ascites: vizi-kórság (i. m.120) 'hasvíz'; Atheroma: fejér genetséggel tellyes daganat (i. m. 92) 'kásadaganat'; Basilica: a könyök alsó részén levő ér (i. m. 39); Brandt ader: nyelv alatt való ér (i. m. 345); Brandt: Orbán (i. m. 229) - TESz.: 'orbánc'; Bronchocela: nyak sérelem (Miskóltzy 1742: XVII); Bubo: undok kelés (i. m. 250) 'nyirokcsomó gyulladásos daganata'; Cancer: Rák (i. m. 98) - ilyen formában a szó itt fordul elö először, bár korábban van már Pázmánynál: fene rák (TESz.); Cephalica: fó-ér (Miskóltzy 1742:

1 A jelentések Brencsán 2006-ból valók. Ha a jelentés nem tőle van, akkor azt külön jelölöm. A jelentéseket ', jelek közé tettem. 
39); Chirurgia: Borbély-Mesterség, Kézi-Seb-Orvoslás (i. m. 3); Clavicula: a nyak alsó részén levő csont (i. m. 308) 'kulcscsont' - Pápai Páriz (1708/1801) szerint: fiók csont; Claviculae: Peretz-csont: Hát hoszszában lévő geréb csontok (Miskóltzy 1742: 11); Coecum: vakbél² (i. m. 66) - A TESz. szerint az első előfordulása Rácznál 1782-ben; convulsio: zsugoradása a' sebnek (Miskóltzy 1742: 331) 'görcs, görcsös vonaglás'; corrosivum: metzés (i. m. 342); Delirium: fönek higulása (i. m. 334) 'tudat elborulása, átmeneti tudatzavar'; destillalt viz: készitett viz (i. m. 412); Epigastrium: bél-Virág, lantorna (i. m. 70) 'gyomortáj'; Esebar: var (i. m. 356); Exomphalos: a köldöknek nyavalája 's igen ki-állása (i. m. 122) 'veleszületett köldöksérv'; Formicosa: férfi mellén lévő kelevények (i. m. 234); Furunculus: Szent Antal tüze (i. m. 83) 'kelés'; gangraena: forró fene vagy Brandt (i. m. 129) 'üszök'; Guga: carbunkulus (i. m. 254) 'furunkulusfajta: darázsfészek'; Gutta Rosacea: artzulatban lévő kelevények (i. m. 232) 'idült értágulat'; Haemorhoides: arany-ér (i. m. 238) - az aranyér szónak ez az első előfordulása! (lásd TESz.); Hernia: sérülés avagy tökössék (Miskóltzy 1742: 124) 'sérv'; Hydrocephalos: Főnek nedvesség miatt-való fájdalma (i. m. 106) 'agykamratágulat'; Ileum: görbe-bél (i. m. 66) 'csípőbél'; [tüdő] lobusai: szárnyai (i. m. 63); 'lebenyei'; Meliceris: embernek térdén könyökin lévő kelevény (i. m. 94); Musculusok: egér formu Inak (i. m. 25); nervus: noli me tangere: mardozó farkas (i. m. 233) - Pápai Páriz 1708/1801 szerint a nervus nemcsak ideget és ínt jelenthetett, hanem húst is; Os Cribrosum vagy Colatorium: spongias csont (Miskóltzy 1742: 10) - se Brencsánnál, sem a régi szótárakban nem találtam meg a latin szavakat, de a töveik alapján feltehetően ez a szita- vagy rostacsontot jelentett (vö. Brencsán: szita= cribrum; rostaszerü = cibriformis); Os Ilion: vég-bélnek csontya (Miskóltzy 1742: 13) - ez valószínűleg téves fordítás, helyesen: 'csípőcsont'; Os Occipitis: Nyak-szün csont (i. m. 9) 'nyakszirtcsont'; Ossa Petrosa temporum: Az két halánték csontok (i. m. 9) 'sziklacsontok'; Ossa Sincipitis: A' Fej' közepin lévő két csontok (i. m. 9); Panaritium: nevetlen féreg (i. m. 239) 'az ujjak phlegmónéja'; Pancreas: fodor bél (mirigy) (i. m. 55) 'hasnyálmirigy'; Paralysis: Gutta-ütés (i. m. 33) 'bénulás'; parasta: hóljag csévéin levő mirigyek; feltehetőleg: 'prosztata' (i. m. 71) - egyébként a prosztata szó először csak 1884-ben fordul elő (TESz.); Parotís: fül-tönek medgye, vagy a fül mellett-való kelés (Miskóltzy 1742: 108) 'fültőmirigy'; Pleuritis: oldal-fájás (i. m. 119) 'mellhártyagyulladás'; Rectum: öreg hurka (i. m. 67); resolutio: el-oszlás (i. m. 91) 'teljes gyógyulás, felszívódás'; Rothlauff: csúsz (i. m. 87); Salvatella: lépre szolgáló ér; Saphaena: rósaér (i. m. 41); Scrophulae, strumae vagy Golyva daganat (i. m. 95) - itt valami zavar van, mert a scrofula más, mint a golyva; Squinantia: Nyakon való kelevény (i. m. 229); Steatoma: testen való dagadás, mellyben fadgyu-szinü nedvesség vagyon (i. m. 93) 'faggyúmirigy'; Styolides: Kéz bokájának csontya ki-fordulása (i. m. 286); Stupor: rémülés, a fej vagy a gerinc megmerevedése (i. m. 334) 'szellemi vagy testi gátoltság'; Testudo vagy Tapla: vakandok dagadás (i. m. 108); Timpanites: dobvizi kórság, ki miatt az Ember megdagad, mint szintén a’ dob (i. m. 120).

2 Félkövérrel jelöltem azokat a szavakat, amelyek Miskóltzynál fordulnak elő először. 
4.2. Csak magyar kifejezést használ a szerző (közel 150 esetben). ${ }^{3}$ A felsorolás nem tartalmazza a közkeletü elnevezéseket (fej, láb, kéz, máj stb.)

Agy-velőnek erővel és természet ellen-való reszketése 'agyrázkódás' (i. m. 174); asszony szülö méhe (i. m. 197); bokában a keze feje (i. m. 206/b); Corona ér (i. m. 37); csont fiókja (i. m. 25); éles matéria 'genny' (i. m. 272); éles 'erős' orvosság (i. m. 186); eleveníteni 'feléleszteni' (i. m. 132); el-hatalmazott sebek (i. m. 329); éllesztő inok 'idegek' (i. m. 50); első fogak 'metszőfogak' (i. m. 17); ember Keze lapitzkái 'lapockái' (i. m. 12); Embernek arczilatya vagy arczéllatya (i. m. 26); Ember szeme szőri (i. m.16); emésztő Torok (i. m. 184); esze nélkül beszél (i. m. 161); eszén vagyon (i. m. 176); észnek tibolodása (i. m. 174); fantáziálás (i. m. 252); farkas daganat (i. m. XXV); farkas hús (i. m. 319); fásli (i. m. 305) - első előfordulása a szónak (TESz.); Fej-velö 'agyvelö' (Miskóltzy 1742: 15); felgyámoltassék 'felpolcoltassék' (i. m. 120); fel-táskásul (i. m. 220); fene ér (i. m. 36); férfi és az asszonyi állat magva az anya-méhben öszveegyenlittetett és abban bézároltatott 'fogantatás' (i. m. 4); fogoknak veleje 'fogban levő ideg' (i. m. 14); Forgó-tsont (i. m. 273); gyomor kevergés (i. m. 253); Gyomor torka 'gyomorszáj' (i. m. 65); hajnevelő (i. m. 23); hamar kéz 'gyors kéz' (i. m. 3); háta gerébnek veleje 'gerincvelő' (i. m. 15); heg-nevelö (i. m. 88); héség (i. m. XXXI); hideg borzogatás (i. m. 330); hideg-vett 'kihült' tagok (i. m. 206); hideg fene (i. m 131); iny-hús (i. m. 285); kéz bokája (i. m. 266, 286) - a TESz. az első előfordulást 1821-ra teszi!; kéz lapitzkái 'lapockák' (Miskóltzy 1742: 12); Kéznek gyökerei (i. m. 34); kéz szára csontya (i. m. 286); ki-gyukott 'kiakadt, kificamodott' (i. m. 320); kis has 'kismedence' (i. m. 70); korona forma ér (i. m. 44); korpás, hal-héjas varr (i. m. 256); körömméreg (i. m. XXXI); kosz vagy rübetegség (i. m. XXXI); lába farka (i. m. 256) - a szó valószínűleg a sarkat jelenti, mivel a farok eredeti jelentései között valaminek a vége, hátsó része jelentése is volt (TESz.); láb-fej (Miskóltzy 1742: 33); láb ikra (i. m. 42); Lába-kásája (i. m. 266) - a TESz. szerint a láb inát, ikráját jelenti, és először csak 1820-ban fordul elö; lábszár kásája (Miskóltzy 1742: 345); lélekzet vévő sip vagy gége (i. m. 35); Lepra vagy bél-poklosság (i. m. 254) - a lepra szó megjelenését a TESz. 1857-re teszi; magtartó edények (Miskóltzy 1742: 71); [ha a pestis valakit] megszökne (i. m. 152); méhnek sípja 'hüvely' (i. m. 41); monya csévéje (i. m. 202); mony feje (i. m. 236) - a mony Miskóltzynál hímvesszőt jelent (TESz.); nyak görözdök (Miskóltzy 1742: 13); nyúl-ajak (i. m. XXXVII); oldal csont (i. m. 12) - itt a jelentése: borda; óldal hártya 'mellhártya' (i. m. 63); ortza: az arc szemöldöktől állig (i. m. 62); öreg uj (i. m. 41); öreg üres ér, melly a Májnak felső részébül szármozik (i. m. 37); persegés (i. m. 232); pina (i. m. 236); pulzus Ér (i. m. 19); pörsenés (i. m. 27); Pulsusnak igen nagy reszketése (i. m. 154); Pulzusnak meg-lankadása (i. m. 159 és 162); Pulsusnak sebes járása (i. m. 252); rosta formu tsont (i. m. 51); Sarkantyú ér (i. m. 347); [seb] ajkai (i. m. 145); Seb meg-avasult (i. m. 189); [a csont] spongyás (i. m. 7); szája circulusa (i. m. 27); szárasztó orvosság (i. m. 210); szél-ér 'nyirokér' (i. m. 25); szem avagy kölök fogak (i. m. 15); szem külső kupája (i. m. 28); szivató tsont (i. m. 226); szivó erek (i. m. 40); sziv

3 A gazdag anyagból csak válogattam. A szavak jelentését, ha szükségesnek láttam, próbáltam a szövegből megállapítani. Itt a ' ' jelek a saját jelentésmegadásaimat jelölik. 
reszketés (i. m. 253); szömötsin 'szemölcs' (i. m. 367); térd-kaláts (i. m. 292); torok (i. m. 73) - itt 'méhszáj'; vér állító orvosság (i. m. 187); vermetske a vállon (i. m. 284); vesztég kell tartani (i. m. 324) - szerintem: 'nyugalomban kell tartani'; vizelletnek bontakozása nélkül... 'ha nem termelödik/nem ürül a vizelet' (i. m. 253) stb.

\subsection{A chirurgusok gyógyításhoz való eszközeinek felsorolása a munkában}

A sebészek munkájára nagy hatással voltak a háborúk. Ezekben sok tapasztalatot szereztek, valószínűleg Miskóltzy Ferentz is. Ezt bizonyítja munkájában az ezredkórház patikájának leírása (Takáts László 1964 klny.: 6-7):

„....a’ Hyrurgusnak az ő Praxisához kivántatik, hogy légyen egy alkalmatos SZELENTZÉJE, amelly-is illendő Instrumentumokkal légyen tellyes, úgymint: „Olló, Tetém-szedö, Spótt, Lék-mérö, Toló-vas, által-húzó Tü, Akasztaló-tséve, különbkülömbféle akasztaló Tü, Borotva, Lantzéta, vagy Ér-vágó vas, Kis reszelö, flastrommal és Ungventummal ruha tépésekkel, s vér-állító szerszámmal légyen el-készítve.

Másodszor szükséges Trepánum, Elevatorium, Separatorium, Hegyes fogó és Reszelö, mellyek a' törött koponyához szükségesek.

Harmadszor: Nyelv emelő 's szájhoz való Sráff, Fetskendö, torokhoz való Drót, Kalánotska, a' le-esett nyak-tsapnak fel-emelésére, külömb külömb-féle Fog-vonók, Pelikán és Ketske-láb; Fogó és Likasztó, a' nyakon-való Setaceumhoz hoszszú sinór, Húzó-tü, Fetskendö és Tsévék, a' meg-sebesedett mellhez, hasonlóképpen a' megrekedett sebhez. Golóbits-húzó, az aszszony méhéhez és vég-bélhez való Sráfok, kiket Tükörnek-is hivnak, nagy és kitsiny lapos Fogó, külömbféle hús-metsző Kések, Tsont-fürész, két Lapos vassal, különb-féle sütö vasak; mellyek rész-szerént 'a tagnak el-metszéséhez 's a' vér-állitásához, és egyebekre is szükségesek.

Negyedszer: Fitzamodásokhoz vagy tsont törésekhez való sráffos Instrumentum, sindenböl készitett különb-különbféle Deszkátskák, Pléh vagy papirosból készittettek, hogy azzal a megtörött tsontot bé-köthessék, és Ládátska, mellyben a' törött lábszár tétessék, karhoz való Sindel, Vánkosok, Fáslik és egyéb ezekhez hasonlók" (Miskóltzy 1742: 361-3; vö. még Simon Katalin 2013: 8).

\section{Miskóltzy érdeme}

Miskóltzy munkájának nagy része németből való fordítás, de az anatómiai nevek többségét latinul írja (nyilván a forrásaiban is így volt), vagy megadja a latin mellett olykor a saját maga alkotta magyar megfelelőt is, amely hol találó, hol elég gyenge, mesterkélt, és nem is mindig felel meg a valóságnak. Nagyon gyakran körülírást alkalmaz. Van azonban néhány orvosi kifejezés, amelyik nála fordul elő elöször (például: aranyér, fásli, kéz bokája, lepra, paraszta, pörsenés, vakbél stb.). Miskóltzy érdeme az, hogy „pártját fogta a megrekedt, lenézett magyar nyelvnek, melyen a tudósok még mindig nem akartak beszélni - megmutatta vele a kétkedőknek, hogy ez a nyelv alkalmas mindenre [...], alkalmas a komoly tudományokra" (Fekete Lajos 1874: 657). 


\title{
SZAKIRODALOM
}

Dr. Ács Géza 2016. A magyarországi sérültellátás és a magyar TraumatológusTársaság története. In: Negyvenéves a Magyar Traumatológus Társaság, Jubileumi könyv. Magyar Tudományos Akadémia, Debrecen, 11-22.

Brencsán János 2006. Orvosi szótár. Medicina Könyvkiadó, Budapest.

Csillag István 1962. 220 éves az első magyar nyelvủ sebészeti tankönyv. Orvosi Hetilap 103: 1083-5.

Fekete Károly 2016. A magyar traumatológia rövid története. A Debreceni Egyetem ÁOK Traumatológiai és Kézsebészeti Tanszék Közleményei, 161-71.

Fekete Lajos 1874. Miskóltzy Ferentz irodalmi munkássága. Gyógyászat XIV/45: 655-7.

Kapronczay Károly 2004. Magyar orvoséletrajzi lexikon. Mundusz Kiadó, Budapest. https:// kereso.startlap.hu/index.php?q=magyar orvoséletrajzi-lexikon. (Letöltés ideje: 2020. január 19.)

Korbuly György 1939-1942. A magyar egészségvédelem felé. In: Domanovszky Sándor (szerk.): Magyar müvelödéstörténet. Magyar Történelmi Társulat, Budapest. https:// www.arcanum.hu/hu/online-kiadvanyok/Domanovszky-domanovszky-magyarmuvelodestortenet-1/negyedik-kotet-barokk-es-felvilagosodas-1007/korbuly-gyorgy-azallami-egeszsegvedelem-fele-12E9/ (Letöltés ideje: 2020. január 20.)

Magyary-Kossa Gyula 1940. Magyar orvosi emlékek. IV. kötet. Magyar Orvosi Könyvkiadó Társulat, Budapest.

Miskóltzy Ferentz 1742. Manuale chirurgicum. Streibig János Gergely, Győr.

Pápai Páriz Ferencz 1708/1801. Dictionarium Latino-Hungaricum. Landerer-Hochmeister, Pozsony.Petz Aladár 1929. Győr szabad királyi város Szentháromság kórházának múltja és jelene 1749-1928. Győr Egyházmegyei Alap Nyomda Műintézete, Győr.

Ralovich Béla 2016. Semmelweis megfigyelésének visszatükröződése a hazai orvosi szakirodalomban. Orvosi Hetilap 157/9: 357-9. https://doi.org/10.1556/650.2016.9M

Simon Katalin 2011. Sebészet és sebészek Magyarországon. Semmelweis Kiadó, Budapest.

Takáts László 1964. A Rákóczi szabadságharc egészségügye. A hadsereg-egészségügy szervezése az 1809-es magyar nemesi felkelésben. Honvédorvos XVI/2: 163-84 (klny. 1-21).

TESz. $=$ Benkő Loránd (szerk.) 1967-1976. A magyar nyelv történeti-etimológiai szótára I-III. Akadémiai Kiadó, Budapest.

\author{
Keszler Borbála \\ professor emeritus \\ ELTE BTK \\ https://orcid.org/0000-0003-2220-7822
}

\section{SUMMARY}

Keszler, Borbála

\section{Ferentz Miskóltzy's medical terms}

Ferentz Miskóltzy is the author of the first known medical treatise in Hungary (Manuale chirurgicum, avagy chirurgiai uti-társ, 1742). The book was written shortly after the end of 
Turkish rule in this country when Hungarian scientific terminology was in fact rather poor. It shows the author's struggle with the Hungarian language especially when he uses medical terms. Most of Miskóltzy's work is a translation from German, but he writes the majority of medical terms in Latin (probably they were in that form in his sources, too). Sometimes, however, he gives, alongside the Latin term, the Hungarian equivalent that he coined himself. Those equivalents are sometimes apt but often artificial or poor and do not even match the intended concept. He also frequently uses circumscriptions. Yet there are a number of his medical terms that are still in use today (e.g. aranyér 'gold vein', fásli 'bandage', kéz bokája 'wrist (lit. hand's ankle)', lepra 'leprosy', pörsenés 'pimples', vakbél 'blind gut'). It is to be ascribed to Miskóltzy's credit that "he took sides with the Hungarian language that had bogged down and been disdained, that scholars refused to use; he showed to the incredulous that this language was fit for everything [...] fit for serious scholarship" (Fekete 1874: 657).

Keywords: Ferentz Miskóltzy, forerunner of language reform, Hungarian translations of Latin medical terms, description of the pharmacy of the regimental infirmary. 